\title{
ASSASSINATING SADDAM HUSSEIN: THE VIEW FROM INTERNATIONAL LAW
}

\author{
Louis René Beres, Ph.D."
}

With war against Iraq an increasingly probable event, ${ }^{\text {*** }}$ the question of assassination looms large in American operational planning. Whether or not such high-level political killing of Saddam Hussein would be in the overall best interests of the United States or its allies is certainly a vital question, but one I will now leave for others. The question to be considered here asks rather if such assassination could be permissible under international law. Following a general jurisprudential assessment of this question, I will examine this issue of permissibility with special reference to counter-terrorism.

Understood as tyrannicide' (killing a tyrant) within a country, assassination has often been accepted as lawful. Support for such a form of assassination can be found in Aristotle's POLITICS, Plutarch's LIVES, and Cicero's DE OFFICIIS. According to Cicero: ${ }^{2}$

There can be no such thing as fellowship with tyrants, nothing but bitter feud is possible: and it is not repugnant to nature to despoil, if you can, those whom it is a virtue to kill; nay, this pestilent and godless brood should be utterly banished from human society. For, as we amputate a limb in which the blood and the vital spirit have ceased to circulate, because it injures the rest of the body, so monsters, who under human guise, conceal the cruelty and ferocity of a wild

* Louis René Beres received his Ph.D. from Princeton University in 1971 and is currently Professor of Political Science and International Law at Purdue University. He is the author of ten books and several hundred scholarly articles and monographs. Born in Switzerland, Professor Beres lectures and publishes widely in the United States and abroad on matters relating to terrorism, nuclear terrorism, nuclear strategy, and nuclear war. Besides being the Strategic and Military Affairs Analyst for The Jewish Press in New York City, he is a wellknown contributor to the Ariel Center for Policy Research and advisor to the Government and Prime Minister of Israel. Professor Beres' columns appear often in The New York Times, Los Angeles Times, USA Today, The Washington Post, The Chicago Tribune, and The Indianapolis Star.

** Professor Beres' paper was presented at the symposium, before the war with Iraq began.

1. See generally THE TERRORISM READER: A HISTORICAL ANTHOLOGY 7-43 (Walter Lacquer ed., 1978).

2. See M.T. Cicero, De Officiis, in THETERRORISM READER: A HISTORICALANTHOLOGY, supra note 1 , at 16. 
beast, should be severed from the common body of humanity. ${ }^{3}$

The eighteenth century Swiss scholar, Emmerich de Vattel, in The Law of Nations, recalls "the essential object of civil society" is to "work in concert for the common good of all." ${ }^{4}$ Hence, he inquires:

Could the society make use of its authority to deliver irrevocably itself and all its members to the discretion of a cruel tyrant? Surely not; since it would lose all rights of its own if it undertook to oppress any part of the citizens. When, therefore, it confers the supreme and absolute power of government without express reserve, there is necessarily an implied reserve that the sovereign will use that power for the welfare of the people and not for their destruction. If he makes himself the scourge of the State he disgraces himself; he becomes no better than a public enemy, against whom the Nation can and should defend itself. And if he has carried his tyranny to the extreme, why should the life itself of so cruel and faithless an enemy be spared?

Even before Vattel, the English poet, John Milton accepted the argument of tyrannicide in justifying the execution of Charles I. According to Milton's Tenure of Kings and Magistrates, "[t]yrannicide, that is the killing of a tyrant,

3. Id. Elsewhere, Cicero - citing approvingly to the Grecks, offers further support for tyrannicide:

Grecian nations give the honors of the gods to those men who have slain tyrants. What have I not seen at Athens? What in the other cities of Greece? What divine honors have I not seen paid to such men? What odes, what songs have I not heard in their praise? They are almost consecrated to immortality in the memories and worship of men. And will you not only abstain from conferring any honors on the saviour [sic] of so great a people, and the avenger of such enormous wickedness, but will you even allow him to be borne off for punishment? He would confess - I say, if he had done it, he would confess with a high and willing spirit that he had done it for the sake of the general liberty; a thing which would certainly deserve not only to be confessed by him, but even to be boasted of.

This is taken from Cicero's speech in defense of Titus Annius Milo, a speech offered on behalf of an instance of alleged tyrannicide committed by Milo, leader of Lanuvium. See M. T. Cicero, The Speech of M. T. Cicero in Defense of Titus Annius Milo, in SELECT ORATIOnS OF M.T. CICERO 208 (C.D. Yonge trans., 1882).

4. These requirements of comity are associated with Vattel's notion of "mutual aid." According to The Law of Nations, "[s]ince Nations are bound mutually to promote the society of the human race, they owe one another all the duties which the safety and welfare of that society require." See EMMERICH De VATTEL, THE LAW OF NATIONS OR THE PRINCIPLES OF Natural LaW Vol. III, xii (George D. Gregory trans., 1916) (1758).

5. Id. at xii. 
is not only lawful, but also laudable." ${ }^{6}$ Of course, as a practical matter, the criteria that can clearly distinguish tyrannical from non-tyrannical rule are very difficult to identify. When John Wilkes Booth leaped onto the stage at Ford Theater after assassinating President Lincoln, he shouted: "Sic semper tyrannis!" Thus always to tyrants!

Without appropriate criteria of differentiation, judgments concerning tyrannicide are inevitably personal and subjective. The hero of Albert Camus' The Just Assassins, Ivan Kaliayev, a fictional adaptation of the assassin of the Grand Duke Sergei, says that he threw bombs, not at humanity, but at tyranny. How shall he be judged? Seneca is reputed to have said that no offering can be more agreeable to God than the blood of a tyrant. But, who is to determine

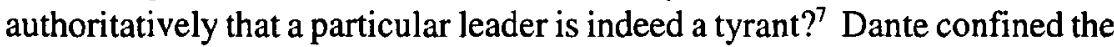
murderers of Julius Caesar to the very lowest depths of hell, but the Renaissance rescued them and the Enlightenment even made them heroes. ${ }^{8}$ In the sixteenth century, tyrannicide became a primary issue in the writings of the Monarchomachs, a school of mainly French Protestant writers. The bestknown of their pamphlets was Vindiciae contra Tyrannos, published in 1579 under the pen name of Junius Brutus, probably Duplessis Mornay, who was a political advisor to the King of Navarre.

The most well-known British works on tyrannicide are George Buchanan's De Jure Regni apud Scotos, published in London in 1579, and Saxby's Killing No Murder, which appeared in 1657. Juan de Mariana, in The King and the Education of the King, says:

[B]oth the philosophers and theologians agree, that the prince who seizes the state with force and arms, and with no legal right, no public, civic approval, may be killed by anyone and deprived of his life and position. Since he is a public enemy and, afflicts his fatherland with every evil, since truly, and in a proper sense, he is clothed with the title and character of tyrant, he may be removed by any means and gotten rid of by as much violence as he used in seizing his power. ${ }^{9}$

In the nineteenth century, a principle of granting asylum to those whose crimes were "political" was established in Europe and in Latin America. This principle is known as the "political offense exception" to extradition. But a specific exemption from the protection of the political offense exception--in effect, an exception to the exception--was made for the assassins of heads of state and for attempted regicides. At the 1937 Convention for the Prevention

6. See John Milton, Tenure of Kings and Magistrates (1648).

7. I am indebted to Walter Laqueur's THE TERRORISM READER for its extended discussion of tyrannicide. See Lacquer, supra note 1, at 7-43.

8. See id. at 8.

9. See Juan De Mariana, The King and the education of the King (1699). 
and Repression of Terrorism, the murder of a head of state, or of any family member of a head of state, was formally designated as a criminal act of terrorism..$^{10}$

The so-called attentat " clause, which resulted from an attempt on the life of French Emperor Napolcon III, and later widened in response to the

10. For current conventions in force concerning terrorism, see Convention on the Prevention and Punishment of Crimes against Internationally Protected Person, Including Diplomatic Agents, Dec. 14, 1973, 28 U.S.T. 1975, T.I.A.S. reprinted in 13 I.L.M. 43 (1974); Vienna Convention on Diplomatic Relations, Apr. 18, 1961, 23 U.S.T. 3227, 500 U.N.T.S. 95; Convention on Offences and Certain Other Acts Committed on Board Aircraft (Tokyo Convention), Sept. 14, 1963, 20 U.S.T. 2941, 704 U.N.T.S. 219; Convention for the Suppression of Unlawful Seizure of Aircraft (Hague Convention), Dec. 16, 1970, 22 U.S.T. 1641; Convention for the Suppression of Unlawful Acts Against the Safety of Civil Aviation (Montreal Convention), Sept. 23, 1971, 24 U.S.T. 564; International Convention Against the Taking of Hostages, G.A. Res. 34/146, U.N. GAOR, 34th Sess., Supp. No. 46, at 245, U.N. Doc. A/34/46 (1979); European Convention on the Suppression of Terrorism, Jan. 27, 1977, E.T.S. 90. On December 9, 1985, the United Nations General Assembly unanimously adopted a resolution condemning all acts of terrorism as "criminal." Never before had the Gencral Assembly adopted such a comprehensive resolution on this question. Yet, the issue of particular acts that actually constitute terrorism was left largcly unaddressed, except for acts such as hijacking, hostage-taking, and attacks on internationally protected persons that were criminalized by previous custom and conventions. See United Nations Resolution on Terrorism, G.A. Res. 40/61, U.N. GAOR, 40th Sess., Supp. No. 53, at 301, U.N. Doc. A/40/53 (1985).

11. The "attentat" clause, included in many treaties, provides that the killing of the head of a foreign government or a member of his family, is not to be considered as a political offense. Some treaties extend the exclusion to any murder or to attempts on any life. Here, the political offense exception to extradition is excluded wherever any killing has taken place. In the absence of an attentat clause in a particular treaty, a state may refuse to extradite persons requested by another state on the ground that the crime in question was political. According to the European Convention on Extradition (Dec. 13, 1957, Council of Europe, Europ. T.S. No. 24:), Article 3, paragraph 3, "The taking or attempted taking of the life of a Head of State or a member of his family shall not be deemed to be a political offense for the purposes of this Convention." Most extradition treaties deny extradition of persons accused or convicted of relative political offenses, i.e. offenses involving one or several common crimes connected with a political act. Assassination is an example of such an offense. The courts of particular states solve the problem of applicability of non-extradition of political criminals by ascertaining the degree of connection between the common crime and the political act. Whether or not the degree of connection required for the act is to be regarded as political, and thus nonextraditable, depends entirely upon the particular test adopted by each individual state. There are three fundamental tests here: (1) the "incidence test" of Anglo-American law, which requires that the crime be part of, or incidental to, a political revolt or disturbance (although Anglo-American decisions involving East European refugees have indicated that extradition will be denied even in the absence of a political revolt or disturbance when the possibility of political persecution can reasonably be demonstrated); (2) the "political objective test" of French law, which requires that the crime be directed against the political organization or structure of the state; and (3) the "political motivation test" of Swiss law, which requires that the crime be assessed in light of the predominant surrounding circumstances and especially the motivations of the offender. A number of major treaties in force stipulate that, for purposes of extradition, political offenses shall not include crimes against humanity, certain crimes of war identified in the 1949 Geneva Conventions and comparable violations of the laws of war not already provided for in these conventions. 
assassination of President James Garfield in the United States, limited the political offense exception in international law to preserve social order. Murder of a head of state or members of the head of state's family was thus designated as a common crime, and this designation has been incorporated into Article 3 of the 1957 European Convention on Extradition. Yet, we are always reminded of the fundamental and ancient right to tyrannicide, especially in the post-Holocaust/post-Nuremberg world order. ${ }^{12}$ It follows that one could argue persuasively under international law that the right to tyrannicide is still overriding and that the specific prohibitions in international treaties are not always binding.

From the standpoint of international law, assassination can become an international crime (possibly an instance of terrorism), when it is carried out against a state official, by a national of the same state and within the territory of that state, only where the assassin flees to another state and requests for extradition are issued and/or where the assassin receives assistance from another state. If, however, the assassination is carried out by a national of another state, whether the location of the killing is the territory of the victim, the territory of the perpetrator or some other state altogether, it is immediately a matter of international law. Although, as we shall soon see, such an assassination is almost always a crime under international law it could conceivably be an instance of a very limited right of "humanitarian intervention." ${ }^{13}$ For this to be the case, however, it would be necessary, inter alia, that the victim had been guilty of egregious crimes against human rights, that these crimes were generally recognized and widely-documented, and that no other means existed to support the restoration of basic human rights.

To this point, we have been dealing with assassination as tyrannicide, with the killing of a head of state or high official by a national of the same state. We have seen that the support for such forms of assassination can be

12. See Report of the International Law Commission, Principles of International Law Recognized in the Charter and Judgment of the Nuremberg Tribunal, U.N. GAOR, 2nd Sess., (1950); U.N. GAOR, 5th Sess., Supp. No. 12, at 11, U.N. Doc. A/1316.

13. The doctrine of humanitarian intervention has elicited a variety of international law reactions. For sources supporting humanitarian intervention, see Tom J. Fatrer, An Inquiry Into the Legitimacy of Humanitarian Intervention, in LAW AND FORCE IN THE NEW INTERNATIONAL ORDER 185, 198 (Lori Fisler Damrosch \& David J. Scheffer eds., 1991) (discussing humanitarian intervention for human rights violations); Michael J. Bazyler, Reexamining the Doctrine of Humanitarian Intervention in Light of Atrocities in Kampuchea and Ethiopia, 23 STAN. J. INT'L L. 547, 597-11 (1987) (setting forth criteria for humanitarian intervention); Robert Lillich, Forcible Self-Help by States to Protect Human Rights, 53 Iowa L. REv. 325, 345 (1967) (justifying humanitarian intervention because existing international mechanisms provide inadequate protection). Contra IAN BROWNLIE, INTERNATIONAL LAW AND THE USE OF FORCE BY STATES 340 (1963) (observing that the disappearance of humanitarian intervention from modern practice presents a beneficial development); LOUIS HENKIN, HOW NATIONS BEHAVE: LAW AND FOREIGN POLICY 105 (1968) (stating law against intervention); PHILIP C. JESSUP, A MODERN LAW OF NATIONS: AN INTRODUCTION 169 (1948) (discussing intervention by state to protect one's own nationals). 
found in certain established traditions in political philosophy but that there is virtually no support in the prevailing international law of extradition. ${ }^{14}$ Although some treaties are vague enough that such assassination might be interpreted as a political offense, and therefore not subject to extradition requests, others subscribe to the attentat principle, which provides a specific exception to the exception-in cases involving assassination of heads of state or their families.

Another possible line of support for assassination as tyrannicide can be extrapolated from the current international law of human rights. ${ }^{15}$ Despite the existence of a well-developed, and precisely codified regime of human rights protections, victims of human rights abuse in particular states have little, if any, redress under international law. Indeed, in the absence of an effective centralized enforcement capability, ${ }^{16}$ international law relies upon insurgency ${ }^{17}$ and humanitarian intervention ${ }^{18}$ as the ultimate guarantors of

14. See M. CHERIFBASSIOUNI, INTERNATIONALCRIMINALLAW: A DRAFT INTERNATIONAL Criminal CoDe (1986); Christopher L. Blakesley, Terrorism, Drugs, International LAW AND THE PROTECTION OF HUMAN LIBERTY (1992); and Christopher L. Blakesley \& Otto Lagodny, Finding Harmony Amidst Disagreement Over Extradition, Jurisdiction, the Role of Human Rights and Issues of Extraterritoriality Under International Criminal Law, 24 VAND. J. TRANSNAT'LL.1 (1991).

15. See Universal Declaration of Human Rights, Dec. 10, 1948, G.A. Res. 217 A (III), U.N. GAOR, at 71, U.N. Doc. A/810, (1948); European Convention for the Protection of Human Rights and Fundamental Freedoms, Nov. 4, 1950 T.S.5; Convention Relating to the Status of Refugees, done July 28, 1951, 189 U.N.T.S. 137 (This Convention should be read in conjunction with the Protocol Relating to the Status of Refugees, adopted by the General Assembly on Dec. 16, 1966, and entered into force, Oct. 4, 1967); Convention on the Political Rights of Women, done Mar. 31, 1953, 27 U.S.T. 1909, 193 U.N.T.S. 135; Declaration on the Granting of Independence to Colonial Countries and Peoples, Dec. 14, 1960, G.A. Res. 1514 (XV), U.N. GAOR, Supp. No. 16, at 66, U.N. Doc. A/4684 (1961); International Convention on the Elimination of All Forms of Racial Discrimination, opened for signature Mar. 7, 1966, 660 U.N.T.S. 195, reprinted in 5 I.L.M. 352 (1966); International Covenant on Economic, Social and Cultural Rights, opened for signature Dec. 19, 1966, G.A. Res. 2200 (XXI), 21 U.N. GAOR, Supp. No. 16, at 49, U.N. Doc. A/6316 (1967), reprinted in 6 I.L.M. 360 (1967), International Covenant on Civil and Political Rights, opened for signature Dec. 19, 1966, G.A. Res. 2200 (XXI), 21 U.N. GAOR, Supp. No. 16, at 52, U.N. Doc. A/6316 (1967), reprinted in I.L.M. 368 (1967); American Convention on Human Rights, done Nov. 22, 1969, O.A.S. Treaty Series No. 36, at 1, O.A.S. Off. Rec. OEA/Ser. L/V/II. 23 Doc. 21 rev. 6 (1979), reprinted in 9 I.L.M. 673 (1970). The Universal Declaration of Human Rights, The International Covenant on Civil and Political Rights (together with its Optional Protocol of 1976), and the International Covenant on Economic, Social and Cultural Rights-known collectively as the International Bill of Rights-serve as the touchstone for the normative protection of human rights.

16. Nonetheless, under the terms of Article 56 of the U.N. Charter, member states are obliged "to take joint and separate action in cooperation with the Organization" to promote human rights. U.N. CHARTER art. 56.

17. International law makes clear that not all forms of insurgency are impermissible, i.e. terroristic. Although, specially-constituted U.N. committees and the U.N. General Assembly have repeatedly condemned acts of international terrorism, they exempt those activities that derive from:

the inalienable right to self-determination and independence of all peoples under colonial and racist regimes and other forms of alien domination and the 
essential human rights. It follows that where humanitarian intervention cannot be reasonably expected, individuals within states have only themselves to provide for proper enforcement of their codified human rights.

What about "humanitarian intervention" and assassination? Can agents of one state legally assassinate officials of other states under the rules of humanitarian intervention? Or is such assassination always a self-evident violation of international law in the present world order? ${ }^{19}$

To a certain extent, the answers to these questions depend upon the absence or presence of a condition of belligerency (war) between the states involved. ${ }^{20}$ In the absence of this condition, assassination of political figures

legitimacy of their struggle, in particular the struggle of national liberation movements, in accordance with the purposes and principles of the Charter and the relevant resolutions of the organs of the United Nations.

Report of the Ad Hoc Committee on International Terrorism, U.N. GAOR 28th Sess., Supp. No. 28, A/9028 (1973). This exemption, from the 1973 General Assembly Report of the Ad Hoc Committee on International Terrorism, is corroborated by Article 7 of the General Assembly's 1974 Definition of Aggression. See The Resolution on the Definition of Aggression, G.A. Res. 3314 (XXIX), U.N. GAOR, Supp. No. 31 at 142, U.N. Doc. A/9631 (1975), reprinted in 13 I.L.M. 710 (1974). See also Declaration on Principles of International Law Concerning Friendly Relations and Cooperation Among States, G.A. Res. 2625 (XXV), U.N. GAOR, Supp. No. 28, at 121, U.N. Doc. A/8028 (1971), reprinted in 9 I.L.M. 1292 (1970). For a comprehensive and authoritative inventory of sources of international law concerning the right to use force on behalf of self-determination, see Aureliu Cristescu, Special Rapporteur of the Sub-Commission on Prevention of Discrimination and Protection of Minorities, The Right to Self-Determination: Historical and Current Development on the Basis of United Nations Instruments, E/CN.4/Sub.2/404/Rev. 1, United Nations, New York (1981).

18. While the theory of international law still oscillates between an individualist conception of the State and a universalist conception of humanity, the post-World War II regime of treaties, conventions, and declarations concerning human rights is necessarily founded upon a reasonably broad doctrine of humanitarian intervention. It is the very purpose of this regime to legitimize an allocation of competences that favors the natural rights of humankind over any particularistic interests of state. As violations of essential human rights are now incontestably within the ambit of global responsibility, the subjectivism of State primacy has been unambiguously subordinated to the enduring primacy of international justice.

19. The concept of "world order" as an organizing dimension of academic inquiry and as a normative goal of international law has its contemporary intellectual origins in the work of Harold Lasswell and Myres McDougal at the Yale Law School; GRENVILLE CLARK \& LOUIS B. SOHN, WORLD PEACE THROUGH WORLD LAW (2nd ed. 1966); and the large body of writings by Richard A. Falk \& Saul H. Mendlovitz. For works by this writer, who was an original participant in the World Law Fund's World Order Models Project, see LOUIS RENE BERES \& Harry Targ, Constructing alternative World Futures: Reordering the Planet (1977). See also PlanNing Alternative wORLd FutURES: VAlUES, METHOdS, AND MODELS (Louis Rene Beres \& Harry Targ eds., 1975); LOUIS RENE BERES, PEOPLE, STATES, AND WORLD ORDER (1981); and LOUIS RENE BERES, REASON AND REALPOLITIK: U.S. FOREIGN POLICY AND WORLD ORDER (1984).

20. Under international law, the question of whether or not a state of war actually exists between states is often ambiguous. Traditionally, it was held that a declaration of war was a necessary condition before "formal" war could be said to exist. Hugo Grotius, for example, divided wars into declared wars, which were legal, and undeclared wars, which were not. See Hugo Grotius, The Law of War and Peace, bk. III, chs. III, V, and XI (1625). By the beginning of the twentieth century, the position that war obtains only after a conclusive 
in another state may represent the crime of aggression or the crime of terrorism. Regarding aggression, Article 1 of the 1974 U.N. Resolution on the Definition of Aggression defines this crime, as "the use of force by a State against the sovereignty, territorial integrity or political independence of another state, or in any other manner inconsistent with the purposes of the United Nations." ${ }^{21}$ In view of the binding rule of nonintervention codified in the Charter ${ }^{22}$ that would normally be violated by transnational assassination, such killing would generally qualify as aggression. Moreover, assuming that transnational assassination constitutes an example of "armed force," the criminalization, as aggression, of such activity may also be extrapolated from Article 2 of the Definition of Aggression,

[t]he first use of armed force by a State in contravention of the Charter shall constitute prima facie evidence of an act of aggression although the Security Council may in conformity with the Charter conclude that a determination that an act of aggression has been committed would not be justified in the light of other relevant circumstances .... ${ }^{23}$

Let us now turn to the status of transnational assassination under international law when a condition of war exists between the states involved. According to Article 23(b) of the regulations annexed to Hague Convention IV of October 18, 1907, respecting the laws and customs of war on land: "It is especially forbidden ... to kill or wound treacherously, individuals

declaration of war by one of the parties, was codified by Hague Convention III. More precisely, this convention stipulated that hostilities must not commence without "previous and explicit warning" in the form of a declaration of war or an ultimatum. See Hague Convention III, Relative to the Opening of Hostilities, 1907, art. 1, 3 NRGT, 3 series, 437. Currently, of course, declaration of war may be tantamount to declarations of international criminality (because of the criminalization of aggression by authoritative international law), and it could be a jurisprudential absurdity to tie a state of war to formal declarations of belligerency. It follows that a state of war may exist without formal declarations, but only if there is an armed conflict between two or more states and/or at least one of these states considers itself at war.

21. See Resolution on the Definition of Aggression, G.A. Res. 3314 (XXIX), 29 U.N. GAOR, Supp. No. 31, at 142, U.N. Doc. A/9631, art. 1, (1975), reprinted in 13 I.L.M. 710.

22. See U.N. CharTer art. 2, paras. 7, 59. See also Declaration on Principles of International Law concerning Friendly Relations and Cooperation Among States in Accordance with the Charter of the United Nations, adopted Oct. 24, 1970, G.A. Res. 2625 (XXV), U.N. GAOR, Supp. No. 28, at 121, U.N. Doc. A/8028 (1971), reprinted in 9 I.L.M. 1292 (1970); G.A. Res. 2625, U.N. GAOR, 25th Sess., Supp. No. 28, at 122-23, U.N. Doc. A/8028 (1970); see also Declaration on the Inadmissibility of Intervention in the Domestic Affairs of States and the Protection of Their Independence and Sovereignty, G.A. Res. 2131 (XX), U.N. GAOR, U.N. Doc. A/RES/2131 (XX)/Rev. 1 (1966).

23. See Resolution on the Definition of Aggression, G.A. Res. 3314 (XXIX), 29 U.N. GAOR, Supp. No. 31, at 142, U.N. Doc. A/9631 (1975), reprinted in 13 I.L.M. 710 (1974). 
belonging to the hostile nation or army."24 U.S. Army Field Manual 27-10, The Law of Land Warfare, which has incorporated this prohibition, authoritatively links Hague Article 23(b) to assassination at Paragraph 31, "[t]his article is construed as prohibiting assassination, proscription or outlawry of an enemy, or putting a price upon an enemy's head, as well as offering a reward for an enemy "dead or alive." 25

From the point of the convergence between international and U.S. municipal law, ${ }^{26}$ the Hague Convention $\mathrm{V}$ is a treaty of the United States that has received the advice and consent of the Senate and is, therefore, the "supreme law of the land" under Article 6 of the Constitution (the "Supremacy Clause"). Indeed, even if Congress were to enact a statute that expressly repealed the rule found at Hague Regulation Article 23(b), that would not permit U.S. officials to legalize assassinations. ${ }^{27}$ This is because, among other things, the Nuremberg Tribunal (1945) expressly ruled that the obligations

24. Hague Convention (IV) Respecting the Laws and Customs of War on Land, U.S.T.S. 539, 2 A.J.I.L. Supp. 90, entered into force Jan. 26, 1910.

25. U.S. DEPT. OF THE ARMY, THE LAW OF LAND WARfare (1956).

26. There are many sources that point to the convergence of national and international law. According to Article VI of the U.S. Constitution, "All treaties made ... under the authority of the United States shall be the supreme law of the land . ..." U.S. CONST. art. VI, cl. 2. Although Article VI refers exclusively to treaties, the process of incorporation has also been extended by several decisions of the Supreme Court to international law in general. As this means that all of the international rules against assassination are now the law of the United States, any attempt to modify prohibitions against assassination would also appear to be in violation of American municipal law. Nevertheless, as we shall see, there are certain circumstances where "Higher Law" and other peremptory expectations of justice may be overriding.

27. Under U.S. law, assassination is prohibited at Executive Order 12,333 of the United States (Dec. 4, 1981) which stipulates, at Part 2, Paragraph 2:11: "No person employed by or acting on behalf of the United States Government shall engage in, or conspire to engage in, assassination." See Exec. Order No. 12,333,3 C.F.R. 200 (1988), reprinted in 50 U.S.C. $\$ 401$ (1988). 
codified at the Hague Regulations had entered into customary international law ${ }^{28}$ as of $1939 .{ }^{29}$

It appears, then, impossible for any state to legalize assassination, and the leaders of any recalcitrant state would be subject to prosecution as hostes humani generis, ${ }^{30}$ "common enemies of mankind" in any state that claimed appropriate jurisdiction. ${ }^{31}$ Significantly, U.S. law recognizes and reinforces these obligations under international law. According to Paragraph 498 of Field Manual 27-10, any person, whether a member of the armed forces or a

28. Article 38(1)(b) of the Statute of the International Court of Justice describes international custom as "evidence of a general practice accepted as law." In this connection, the essential significance of a norm's customary character under international law is that the norm binds even those states that are not parties to the pertinent codifying instrument or convention. With respect to the bases of obligation under international law, even where a customary norm and a norm restated in treaty form are apparently identical, the norms are treated as separate and discrete. During the merits phase of Military and Paramilitary Activities in and Against Nicaragua, the International Court of Justice (ICJ) stated: "Even if two norms belonging to two sources of international law appear identical in content, and even if the States in question are bound by these rules both on the level of treaty-law and on that of customary international law, these norms retain a separate existence." Military and Paramilitary Activities (Nicaragua v. U.S.), 1986, I.C.J. 14 (June 27). Further, in many states, customary international law is binding and self-executing, but an act of the legislature is required to transform conventional law into municipal law.

29. Affirmation of the Principles of International Law Recognized by the charter of the Nuremberg Tribunal, adopted Dec. 11, 1946, G.A. Res. 95 (I), U.N. GAOR, at 1144, U.N. Doc. $A / 236$ (1946). From the point of view of the United States, the Nuremberg obligations are, in a sense, doubly binding. This is the case because these obligations represent not only current normative obligations of international law, but also the higher law obligations engendered by the American political tradition. By its codification of the principle that fundamental human rights are not an internal question for each State, but an imperious postulate of the international community, the Nuremberg obligations represent a point of perfect convergence between the law of nations and the jurisprudential/ethical foundations of the American Republic.

30. See Filartiga v. Pena-Irala, 630 F.2d 876 ( $2 \mathrm{~d} \mathrm{Cir.} \mathrm{1980)} \mathrm{("The} \mathrm{torturer} \mathrm{has} \mathrm{become} \mathrm{-}$ like the pirate and slave trader before him - Hostes humani generis, an enemy of all mankind."). Id. at 890 .

31. The principle of universal jurisdiction is founded upon the presumption of solidarity between the states in the fight against crime. It is mentioned in the Corpus Juris Civilis; GROTIUS, supra note 20, bk. II, ch. 20; and in EMERICH VATTEL, LE DROIT DES GENS bk. I, ch. 19 (1758). The case for universal jurisdiction (which is strengthened wherever extradition is difficult or impossible to obtain) is also built into the four Geneva Conventions of Aug. 12, 1949, which unambiguously impose upon the High Contracting Parties the obligation to punish certain grave breaches of their rules, regardless of where the infraction was committed or the nationality of the authors of the crimes. See Geneva Convention (I) relative to the Treatment of Prisoners of War, art. 49, 75 U.N.T.S. 135, entered into force Oct. 21, 1950; see also Geneva Convention (II) for the Amelioration of the Condition of Wounded, Sick and Shipwrecked Members of Armed Forces at Sea, art. 50, 75 U.N.T.S. 85, entered into force Oct. 21, 1950; see also Geneva Convention relative to the Protection of Civilian Persons in Time of War, art. 146, 75 U.N.T.S. 287, entered into force Oct. 21, 1950. In further support of universality for certain international crimes, see M. CHERIFB ASSIOUNI, INTERNATIONALEXTRADITION: UNITED STATES LAW AND PRACTICE 91, 91 (3rd ed. 1996). See also RESTATEMENT OFTHE FOREIGN RELATIONS LAW OFTHE UNITED STATES, § 402-04, 443 (Tentative Draft Nov. 5, 1984); 18 U.S.C. § III 6(c) (2003). 
civilian, who commits an act that constitutes a crime under international law, is responsible for the crime and is liable to punishment. ${ }^{32}$ Paragraph 501 of the same Field Manual, based upon the well-known judgment of Japanese General Yamashita, stipulates that any U.S. government official who had actual knowledge, or should have had knowledge, that troops or other persons under his control were complicit in war crimes and failed to take necessary steps to protect the laws of war was guilty of a war crime. ${ }^{33}$ And Paragraph 510 denies the defense of "act of state" to such alleged criminals by providing that, though a person who committed an act constituting an international crime may have acted as head of state or as a responsible government official, he is not relieved, thereby, from responsibility for that act. ${ }^{34}$

These facts notwithstanding, there are circumstances wherein the expectations of the authoritative human rights/counterterrorist regime must override the ordinary prohibitions against transnational assassination - both the prohibitions concerning conditions of peace and conditions of war. The most apparent of such circumstances are those involving genocide ${ }^{35}$ and related crimes against humanity. ${ }^{36}$ If, after all, the assassination of a Hitler ${ }^{37}$ or a Pol Pot could save thousands or even millions of innocent people from torture and murder - it would be a far greater crime not to attempt such an assassination than to actually carry it out. ${ }^{38}$

32. See U.S. DEP'T OFTHE ARMY, supra note 25, I 498.

33. See id. 9501.

34. See id. II 510.

35. See Convention on the Prevention and Punishment of the Crime of Genocide, opened for signature Dec. 9, 1948, entered into force Jan. 12, 1951, 78 U.N.T.S. 277.

36. See id. Regarding the history of U.S. commitment to the Convention, it was submitted to the Senate by President Harry S. Truman in June 1949. The Convention languished in that body until February 19, 1986, when the Senate consented to ratification with the reservation that legislation be passed that conforms U.S. law to the precise terms of the Treaty. This enabling legislation was approved by Congress in October 1988, and signed by President Reagan on November 4, 1988. This legislation amends the Criminal Code of the United States to make genocide a Federal offense. It also sets a maximum penalty of life imprisonment when death results from a criminal act defined by the law. This follows the practice of implementing legislation already well-established with respect to other categories of crimes under international law.

37. According to Franz Neumann, "[i]f one analyzes the reaction of public opinion to the attempt on Hitler's life (July 20, 1944) one is struck by the fact that the right to assassinate him was never questioned by the Western world, which merely complained of the lack of its success." Franz Neuman, On The Limits of Justifiable Disobedience in THE DEMOCRATIC AND THE AUTHORITARIAN STATE 150 (1957).

38. Although the reasonableness of such assassination might be based entirely on the expectations of Nullum crimen sine poena. "No crime without a punishment," it would be substantially greater where particularly egregious crimes are still underway and/or are still being planned. Here assassination would represent an expression of humanitarian intervention and/or anticipatory self-defense. 
Yet, our real objection to Saddam Hussein has little or nothing to do with his brutal pre and post-war reigns of terror in Iraq. ${ }^{39}$ When Saddam destroyed large numbers of Kurds and other allegedly dissident Iraqis before and after his takeover of Kuwait, there was barely a murmur in Washington. ${ }^{40}$ Indeed, the first Bush administration and certain members of Congress deliberately_overlooked these monstrous violations of human rights in the presumed interests of an American Realpolitik. ${ }^{4 !}$

Why, precisely, might we now seek to rid the world of this particular tyrant? Since "humanitarian intervention" may not apply, what grounds for assassination, if any, exist under international law ${ }^{42}$ To answer this question

39. For a comprehensive consideration of Iraqi crimes committed during the Gulf War, see Jordan J. Paust, Suing Saddam: Private Remedies for War Crimes and Hostage-Taking, 31 VA. J. INT'L L. 351 (1991); Louis Rene Beres, The United States Should Take the Lead in Preparing Intermational Legal Machinery for Prosecution of Iraqi Crimes, 31 VA. J. INT'LL. 381 (1991); William V. O'Brien, The Nuremberg Precedent and the Gulf War, 31 VA. J. INT'L L. 391(1991); and John Norton Moore, War Crimes and the Rule of Law in the Gulf Crisis, 31 VA. J. INT'L L. 403 (1991).

40. See Patrick E. Tyler, U.S. to Help Retrieve Data on Iraqi Torture of Kurds, N.Y. TiMEs, May 17, 1992, at 3Y; see also David A. Korn, Genocide of the Kurds, Christian SCIENCE MONITOR, Mar. 13, 1992, at 18; see also Chris Hedges, Deep in the Marshland of Iraq, Flame of Revolt Still Flickers, N.Y. TIMES, Mar. 15, 1992, at 1, 6.

41. See Mass Killings in Iraq: Hearings Before the Committee on Foreign Relations, 102nd Congress, 2nd Sess. 51 (1992). See also Louis Rene Beres, After the Gulf War: Iraq, Genocide and International Law, 69 U. DET. MERCY L. REV. 13 (1991); Louis Rene Beres, Iraqi Crimes and International Law: The Imperative to Punish, 21 DENV. J. INT'L L. \& POL'Y 335 (1993); Louis Rene Beres, Iraqi Crimes During and After the Gulf War: The Imperative Response of International Law, 15 LOY. L.A. INT'L \& COMP. L. REV. 675 (1993); Louis Rene Beres, Iraqi Deeds and International Law: The Question of Punishment, 14 JERUSALEM J. INT'L RELATIONS 22 (1992); Louis Rene Beres, Prosecuting Iraqi Crimes Against lsrael During the Gulf War: Jerusalem's Rights Under International Law, 9 ARIZ. J. INT'L \& COMP. L. 337 (1992); Louis Rene Beres, Prosecuting Iraqi Crimes: Fulfilling the Expectations of International Law After the Gulf War, 10 DICK J. INT'L L. 425 (1992); Louis Rene Beres, Prosecuting Iraqi Crimes Under Intemational Law: An American Constitutional Imperative, 15 Hous. J. INT'L. L. 91 (1992); Louis Rene Beres, Prosecuting Iraqi Gulf War Crimes: Allied and Israeli Rights Under International Law, 16 HASTINGS INT'L \& COMP. L. REV. 41 (1989); Louis Rene Beres, Toward Prosecution of Iraqi Crimes Under International Law: Jurisprudential Foundations and Jurisdictional Choices, 22 CAL. W. INT'LL. J. 127 (1991); see Beres, supra note 35, at 381-90; Louis Rene Beres, Prosecuting Iraqi Crimes Under International Law: An American Constitutional Imperative, Occasional Paper, The Joan B. Kroc Institute for International Peace Studies, University of Notre Dame (1992); Louis Rene Beres, Punishing Genocide and Crimes Against Humanity After the Gulf War: Iraqi Crimes and International Law, 41 Occasional Paper, Graduate Institute of International Studies, Programme For Strategic and International Security Studies, Geneva, Switzerland (1992).

42. Ironically, the United Nations, which is responsible for most of the post-Nuremberg codification of the international law of human rights, has sometimes been associated with increased limits on the doctrine of humanitarian intervention. These limits, of course, flow from the greatly reduced justification for the use of force in the Charter system of international law, especially the broad prohibition contained in Article 2 (4). Yet, while it cannot be denied that humanitarian intervention might be used as a pretext for naked aggression, it is also incontestable that a too-literal interpretation of 2 (4) would summarily destroy the entire corpus of normative protection for human rights--a corpus that is coequal with "peace" as the central 
authoritatively, we should now consider the idea of assassination as anticipatory self-defense. ${ }^{43}$

International law is not a suicide pact. The right of self-defense by forestalling an attack was already established by Hugo Grotius in Book II of The Law of War and Peace in 1625. ${ }^{44}$ Recognizing the need for "present danger" and threatening behavior that is "imminent in a point of time," Grotius indicates that self defense is to be permitted not only after an attack has already been suffered, but also in advance - where "the deed may be anticipated." 45 Or as he says a bit further on in the same chapter: "It be lawful to kill him who is preparing to kill ...."

Let us recall here also Pufendorf's argument in On the Duty of Man and Citizen According to Natural Law:

Where it is quite clear that the other is already planning an attack upon me, even though he has not yet fully revealed his intentions, it will be permitted at once to begin forcible self defense, and to anticipate him who is preparing mischief, provided that there be no hope that, when admonished in a friendly spirit, he may put off his hostile temper; or if such admonition be likely to injure our cause. Hence, he is to be regarded as the aggressor, who first conceived the wish to injure, and prepared himself to carry it out. But the excuse of self-defense will be his, who by quickness shall overpower

objective of the Charter. Moreover, in view of the important nexus between peace and human rights, a nexus in which the former is very much dependent upon widespread respect for human dignity, a too-literal interpretation of 2 (4) might well impair the prospects for long-term security. It must be widely understood that the Charter does not prohibit all uses of force and that certain uses are clearly permissible in pursuit of basic human rights. Notwithstanding, its attempt to bring greater centralization to legal processes in world politics, the Charter system has not impaired the long-standing right of individual States to act on behalf of the international legal order. In the continuing absence of effective central authoritative processes for decision and enforcement, the legal community of humankind must continue to allow, indeed, must continue to require humanitarian intervention by individual States.

43. For writings by this author on anticipatory self-defense under international law, see Louis Rene Beres, On Assassination as Anticipatory Self-Defense: Is It Permissible?, 70 U. DET. MERCY L. REV. U. 13 (1992); Louis Rene Beres, On Assassination as Anticipatory SelfDefense: The Case of Israel, 20 HOFSTRA L. REV. 321 (1991); Louis Rene Beres, Preserving the Third Temple: Israel's Right of Anticipatory Self-Defense Under International Law, 26 VAND. J. TRANSNAT'LL. 111 (1993); Louis Rene Beres, After the Gulf War: Israel, Preemption and Anticipatory Self-Defense, 13 Hous. J. INT'LL. 259 (1991); Louis Rene Beres, Israel and Anticipatory Self-Defense, 8 ARIZ. J. INT' L\& COMP. L. REV. 89 (1991); Louis Rene Beres, After the Scud Attacks: Israel, 'Palestine, 'and Anticipatory Self-Defense, 6 EMORY INT'LL. REV. 71 (1992).

44. See Hugo Grotius, Of The Causes of War; and First of Self Defense, and Defense Of Our Property reprinted in 2 CLASSICS OF INTERNATIONAL LAW 168-75 (Carnegie Endowment Trust 1925) (1625).

45. See Hugo Grotius, The Law of War and Peace 169-85 (Francis W. Kelsey trans., 1925) (1625). 
his slower assailant. And for defense, it is not required that one receive the first blow, or merely avoid and parry those aimed at him. ${ }^{46}$

But what particular strategies and tactics may be implemented as appropriate instances of anticipatory self-defense? Do they include assassination? The customary right of anticipatory self-defense has its modern origins in the Caroline incident, which concerned the unsuccessful rebellion of 1837 in Upper Canada against British rule (a rebellion that aroused sympathy and support in the American border states). ${ }^{47}$ Following this case, the serious threat of an armed attack has generally been taken to justify militarily defensive action. In an exchange of diplomatic notes between the governments of the United States and Great Britain, then U.S. Secretary of State Daniel Webster outlined a framework for self-defense that did not require an actual attack. Here, military response to a threat was judged permissible so long as the danger posed was "instant, overwhelming, leaving no choice of means and no moment for deliberation." 48

Today, some scholars argue that the customary right of anticipatory selfdefense articulated by the Caroline has been overridden by the specific language at Article 51 of the UN Charter. ${ }^{49}$ In this view, Article 51 fashions a new and far more restrictive statement of self-defense, one that does rely on the literal qualifications contained in the expression "if an armed attack occurs." This interpretation ignores that international law cannot compel a state to wait until it absorbs a devastating or even lethal first strike before acting to protect itself. The argument against the restrictive view of self defense is reinforced by the apparent weakness of the Security Council in offering collective security against an aggressor - a weakness that is especially apparent in the case of Iraq.

But we are still left with the problem of demonstrating that assassination can be construed, at least under certain very limited circumstances, as an appropriate expression of anticipatory self-defense. To an extent, the enhanced permissibility of anticipatory self-defense that follows generally from the growing destructiveness of current weapons technologies may be paralleled by the enhanced permissibility of assassination as a particular preemptive strategy. Indeed, where assassination as anticipatory self-defense may actually prevent a nuclear or biological or other highly destructive form

46. See Samuel Pufendorf, On The Duty of Man and Citizen according to NaTURAL LAW, bk. 1, ch. 5 (James Tully ed., Michael Silverthorne trans., 1991).

47. See J. MOORE, A DigEST OF INTERNATIONAL LAW 409 (1906).

48. Id. at 412.

49. Article 51 states that "[n]othing in the present Charter shall impair the inherent right of individual or collective self-defense if an armed attack occurs against a Member of the United Nations, until the Security Council has taken measures necessary to maintain international peace and security." U.N. CHARTER, art. 51, para. 1. 
of warfare, reasonableness dictates that it could represent distinctly or even especially law-enforcing behavior.

Of course, for this to be the case, a number of particular conditions would need to be satisfied. First, the assassination itself would have to be limited to the greatest extent possible to those authoritative persons in the prospective attacking state (in our deliberations, Saddam Hussein). Second, the assassination would have to conform to all of the settled rules of warfare as they concern discrimination, proportionality ${ }^{50}$ and military necessity. Third, the assassination would need to follow intelligence assessments that point persuasively to preparations for unconventional or other forms of highly destructive warfare. And fourth, the assassination would need to be founded upon carefully-calculated judgments that it would, in fact, prevent the intended aggression, and that it would do so with substantially less harms to civilian $^{51}$ populations than would alternative forms of anticipatory selfdefense.

Significantly, the current Bush administration is already on record as favoring a broadened concept of anticipatory self-defense. On September 20, 2002, the President issued The National Security Strategy for the United States of America. ${ }^{52}$ This new American doctrine asserts that traditional notions of deterrence will not work against the new kind of enemy. "We must," says the document, "adapt the concept of imminent threat to the capabilities and objectives of today's adversaries."53 This timely and essential "adaptation" means nothing less than striking first against particularly dangerous adversaries whenever necessary.

Should this broadened idea of anticipatory self-defense include assassination? In view of President Bush's insistent allegations that Saddam

50. The principle of proportionality has its origins in the Biblical Lex Talionis (law of exact retaliation). The "eye for eye, tooth for tooth" expression is found in three separate passages of the Torah. In contemporary international law, the principle of proportionality can be found in the traditional view that a state offended by another state's use of force can - if the offending state refuses to make amends - take "proportionate" reprisals. See INGRID DETTER DE LUPIS, THE LAW OF WAR 75 (1987). Evidence of the rule of proportionality can also be found in Article 4 of the United Nations Covenant on Civil and Political Rights of 1966. Similarly, Article 15 of the European Convention on Human Rights provides that in time of war or other public emergency, contracting parties may derogate from the provisions, on the condition of rules of proportionality. And the American Convention on Human Rights allows at Article 27(1) such derogations "in time of war, public danger or other emergency which threatens the independence or security of a party" on condition of proportionality.

51. Pursuant to the 1949 Geneva Convention IV, civilians are "persons taking no active part in the hostilities, including members of the armed forces who have laid down their arms and those hors de combat by sickness, wounds, detention, or any other cause." Geneva Convention Relative to the Protection of Civilian Persons in Time of War, Aug. 12, 1949, art. 3, para. 1, 75 U.N.T.S. 287.

52. See The National Security Strategy of the United States of America, available at http://www.whitehouse.gov/nsc/ nss.html (last visited Apr. 10, 2003).

53. Id. 
Hussein supports terrorist enemies of the United States, ${ }^{54}$ would such assassination be an authoritative expression of counter-terrorism? Normally we think of anticipatory self-defense in terms of military operations against enemy forces and infrastructures. ${ }^{55}$

What, precisely, are the Bush administration allegations? Regarding Saddam Hussein's support for international terrorism, ${ }^{56}$ Iraq is one of seven countries that have been designated by the Secretary of State as state sponsors of terrorism. UN Security Council Resolution 687 prohibits Saddam Hussein from committing or supporting terrorism, or allowing terrorist organizations to operate in Iraq. ${ }^{57}$ Saddam Hussein, alleges President Bush, continues to violate these United Nations Security Council expectations:

In 1993, the Iraqi Intelligence Service (IIS) directed and pursued an attempt to assassinate, through use of a powerful car bomb, former U.S. President George Bush and the Emir of Kuwait. Kuwaiti authorities thwarted the terrorist plot and arrested 16 suspects, led by two Iraqi nationals.

54. See generally the many stories reporting Secretary of State Colin L. Powell's presentation to the United Nations Security Council on Wednesday, February 5, 2003. For example see The Case Against Iraq, NEWSHOUR WITH JIM LEHRER - PBS, Feb. 5, 2003, available at http://www.pbs.org/newshour/bb/middle_east/jan-june03/case_2-5.html (last visited May 18, 2003). In that presentation, Powell argued, correctly, that Iraq has not complied with Resolution 1441 (which offered it a "final opportunity" to disarm voluntarily) and that it in league with various terrorist organizations.

55. According to Title II, Sec. 201 (4) of The Comprehensive Terrorism Prevention Act of 1995: "The President should use all necessary means, including covert action and military force, to disrupt, dismantle and destroy infrastructures used by international terrorists, including terrorist training facilities and safe havens." The Comprehensive Terrorism Prevention Act of 1995, S. 735, 104th Cong., 1st Sess., U.S. Senate (1995).

56. Here we must also recall Saddam Hussein's infliction of eco-terrorism in Kuwait at the end of the Gulf War. For an exhaustive and authoritative assessment of Iraqi crimes against the environment, including the torching of Kuwaiti oil wells, see The Environmental Aftermath of the Gulf War: A Report Prepared for the Committee on Environment and Public Works, Gulf Pollution Task Force, by the Environment and Natural Resources Policy Division. American Law Division, and the Science Policy Research Division of the Congressional Research Service, 102nd Cong., 2nd Sess., S.PRT, 102-84, Mar. 1992, Washington D.C.: U.S. Govt., 1992. [hereinafter Environmental Aftermath]. The Senate Gulf Pollution Task Force reviewed the applicable principles of international law that governed Iraq's actions, and reaffirmed, inter alia, the fundamental principle of responsibility for transnational harm. This principle is grounded in the expression of customary international law that "[a] State is bound to prevent such use of its territory as, having regard to the circumstances, is unduly injurious to the inhabitants of the neighboring State." Id. See generally MuHammad SadiQ \& John C. MCCain, THE GulFWar AFTERMATH: AN ENVIRONMENTAL TRAGEDY (1993).

57. Other Security Council resolutions condemn terrorism in general. For example, Security Council Resolution 1373 (2001) calls for suppressing financing and improving international cooperation. This Resolution also creates a special committee to monitor implementation. See Security Council Resolution 1373, United Nations Website, available at http://www.un.org/News/Press/docs/2001/sc7158.doc.htm (last visited Apr. 10, 2003). 
Iraq shelters terrorist groups including the Mujahedine-Khalq Organization (MKO), which has used terrorist violence against Iran and in the 1970s was responsible for killing several U.S. military personnel and U.S. civilians.

Iraq shelters several prominent Palestinian terrorist organizations in Baghdad, including the Palestine Liberation Front (PLF), which is known for aerial attacks against Israel and is headed by Abu Abbas, who carried out the 1985 hijacking of the cruise ship Achille Lauro and murdered U.S. citizen Leon Klinghoffer. ${ }^{58}$

Iraq shelters the Abu Nidal Organization, an international terrorist organization that has carried out terrorist attacks in twenty countries, killing or injuring almost 900 people. Targets have included the United States and several other Western nations. Each of these groups has offices in Baghdad and receives training, logistical assistance and financial aid from the government of Iraq.

In April 2002, Saddam Hussein increased from $\$ 10,000$ to $\$ 25,000$ the money offered to families of Palestinian suicide/homicide bombers. The rules for rewarding suicide/homicide bombers are strict and insist that only someone who blows himself up with a belt of explosives gets the full payment. Payments are made on a strict scale, with different amounts for wounds, disablement, death as a "martyr" and $\$ 25,000$ for a suicide bomber ....

Former Iraqi military officers have described a highlysecret training facility in Iraq where both Iraqis and non-Iraqi Arabs receive training on hijacking planes and trains, planting explosives in cities, sabotage and assassinations. ${ }^{59}$

58. This PLO murder of an American in a wheelchair led to a case in U.S. federal court holding that the PLO fails to meet the internationally-accepted definition of a state. See Klinghoffer v. S.N.C. Achille Lauro, 937 F.2d 44, 47 (2d Cir. 1991) citing National Petrochemical Co. v. M.T. Stolt Sheaf, 860 F. 2d 551, 553 (2d Cir. 1988) cert. denied, 489 U.S. 1091 (1989), (quoting RESTATEMENT (THIRD) OFTHEFOREIGN RELATIONS LAW OFTHEUNITED STATES, Sec. 201 (1987)). In Klinghoffer, the PLO characterized itself as "the embodiment of the nationhood and sovereignty of the Palestinian people ...." and "The State of Palestine is the state of Palestinians wherever they may be." Klinghoffer, 937 F.2d at 46-47. The court considered these assertions as further evidence that the PLO lacked the requisite characteristics of a state. See id. at 47.

59. See President George W. Bush, Saddam Hussien's Support for International Terrorism, The White House, Nov, 4, 2002 available at http:/www.whitehouse.gov/infocus/ iraq/decade/sect5.html (last visited May 18, 2003). See also Frank Gaffney, Iraq and Al Qaeda, WASH. TIMES, Jan. 28, 2003. 
Should Saddam Hussein be assassinated to protect the United States against terror, especially against weapons of mass destruction attacks? In view of the persistent failure of the international community to secure his compliance with indispensable Security Council expectations regarding weapons of mass destruction, the only alternative to such methods will very likely be Iraqi aggression involving chemical, biological, and nuclear arms, or Iraqi-assisted terrorism. ${ }^{60}$ Unless we are willing to accept such aggression and terrorism, terrorism that could be extended by selected Arab/Islamic groups granted CBN agents by the Iraqi dictator - assassination of Saddam could surely be the least injurious and most righteous option. Regarding terror groups that could be armed with Iraqi mass-destruction technologies and weapons in the absence of precise regime-targeting by the United States, these groups could potentially inflict great harms upon our own country, further strengthening the American case for assassination as anticipatory self-defense.

It is often necessary, under international law, to offend certain norms in order to implement others. There are circumstances wherein assassination, usually regarded as a violation of myriad customary and conventional rules, represents the only impediment to Nuremberg-category crimes. These circumstances are important, and need to be considered carefully, in the ongoing matter of Saddam Hussein.

Abhorrent as it may seem, assassination does have a proper place in the enforcement of international law. To be sure, this place is small and residual, but it must be acknowledged nonetheless. Although an ideal world legal order would contain neither victims nor executioners, ${ }^{61}$ such an arrangement of global power and authority is assuredly not yet on the horizon. We do not live

60. The argument that Saddam Hussein's WMD threat to the United States is closely linked to the terror threat has been made repeatedly by the Bush administration. Speaking to the Council on Foreign Relations on January 23, 2003, Deputy Secretary of Defense Paul Wolfowitz said:

[t]he threat posed by the connection between terrorist networks and states that possess these weapons of mass terror presents us with the danger of a catastrophe that could be orders of magnitude worse than September 11 th. Iraq's weapons of mass terror and the terror networks to which the Iraqi regime are linked are not two separate themes - not two separate threats.

U.S. Dept. of State, Iraq is Still Unwilling to Disarm. Wolfowitz Says, available at http://usinfo.state.gov/topical/pol/conflict/wolfir23.htm (last visited May 18, 2003).

61. This phrase is taken from AlBert CAMUS, NeITHER VICTIMS NOR EXECUrIONERS (Dwight McDonald ed., 1968). Confronting what he called "our century of fear," Camus asked us all to be "neither victims nor executioners," living not in a world in which killing has disappeared ("we are not so crazy as that"), but one wherein killing has become illegitimate. See id. at 1. This is a fine expectation, to be sure, but not one that can be taken as realistic. Deprived of the capacity to act as lawful executioners, both states and individuals within states, facing aggression and/or egregious human rights violations, would be forced by Camus' reasoning to become victims. The problem with Camus' argument is that the will to kill remains unimpressed by others' commitments to "goodness." This means that both within states and between them, executioners must have their rightful place, and that without these executioners there would only be more victims. 
in the best of all possible worlds, and persistent avoidance of defensive war with Iraq at all costs will ultimately produce war and terrorism by Iraq at altogether terrible costs to us and to certain of our allies. Moreover, a war fought to remove Saddam from power - a war shaped by the assassination imperative-could be vastly less injurious than a war fought to bring total defeat to Iraq. ${ }^{62}$ In this sense, contrary to conventional wisdom on the matter, assassination could actually represent a substantially life-saving use of armed force in world politics. ${ }^{63}$

So optimally, we would remove Saddam Hussein with minimal harm to all others. Interestingly, such a dual objective was already examined in classic international legal thought by Samuel Pufendorf:

As for the force employed in war against the enemy and his property, we should distinguish between what an enemy can suffer without injustice, and what we cannot bring to bear against him, without violating humanity. For he who has declared himself our enemy, inasmuch as this involves the express threat to bring the worst of evils upon us, by that very act, so far as in him lies, gives us a free hand against himself, without restriction. Humanity, however, commands that, so far as the clash of arms permits, we do not inflict more mischief upon the enemy than defense, or the vindication of our right, and security for the future, require. ${ }^{64}$

Assassination, like war, will not simply go away. The point, therefore, is not to pretend and to manipulate, but to try to operate within clear constraints, with precise objectives and according to jurisprudentially correct

62. Nonetheless, in some classical texts, bringing total defeat to an aggressor state such as Iraq would be entirely consistent with international law. Emmerich de Vattel, for example, extends the principle of Hostes humani generis from individuals to nations, and even insists that collective wrongdoers be dealt with just as harshly as individuals. Hence, he argues:

Nations which are always ready to take up arms, when they hope to gain something thereby, are unjust plunderers; but those who appear to relish the horrors of war, who wage it on all sides without reason or pretext, and even without other motive than their savage inclinations, are monsters, and unworthy of the name of men. They should be regarded as enemies to the human race, just as in civil society persons who follow murder and arson as a profession commit a crime not only against the individuals who are victims of their lawlessness, but against the State of which they are the declared enemies. Other Nations are justified in uniting together as a body, with the object of punishing, and even of exterminating, such savage peoples.

VATTEL, supra note 4, at 93.

63. Here we may take special note of the following: Ubi cessat remedium ordinarium, ibi decurritur ad extraordinarium. "Where the ordinary remedy fails, recourse must be had to an extraordinary one." See BLACK's LAW DiCTIONARY 1520 (6th ed. 1990).

64. See Samuel Pufendorf, On the Duty of Man and Citizen According to NATURAL LAW, Vol. II 139(Frank Gardner Moore trans., 1964). 
standards. Ideally, our leaders, in conjunction with others in the United Nations, would soon set to work on a "Draft Code" concerning assassination. An expected outcome of such a codification effort, which would have substantial precedent in international criminal law, ${ }^{65}$ could be a stricter regulation of assassination as a transnational activity and corollary reductions in associated peripheral harms (reductions bringing assassination within the ambit of humanitarian international law).

The only alternative is "business as usual," pretending that assassination is not a juridical matter of concern. Such pretense will not inhibit the incidence of assassination and it will ensure a continuing incapacity to bring such forms of killing under effective legal guidelines and controls. If we can accept that so intrinsically an ungovernable activity as war should be regulated by law, we should also be able to accept codified regulations for assassination (which can, of course, be undertaken within war).

In the matter of Saddam Hussein, assassination options should be conceived and implemented with respect to fully permissible expectations of anticipatory self-defense. Acknowledging that this is not yet the "best of all possible worlds," we must always understand that sometimes the reluctance to use such seemingly violent options would only produce more corpses. As President Bush likely understands, failure to assassinate Saddam now can only result in large-scale losses of innocent life later, losses that could be generated by terrorism as well as by aggressive war.

In the event that the United States waits until the onset of war to commence assassination attempts against Saddam Hussein, it could argue correctly that even an enemy official - so long as he operates within the military chain of command - is a proper combatant and is not an enemy hors de combat. By this reasoning that certain enemy officials can be lawful targets, assassination can be supported if there are no coincident violations of the Law of War.

Adherents of the position that assassination of enemy officials in wartime may be permissible could offer two plausible bases of jurisprudential support. First they could argue that such assassination does not evidence behavior that is designed "to kill or wound treacherously," as defined at Article 23(b) of Hague Convention IV. ${ }^{66}$ Second, they could argue that there is a "higher" or jus cogens obligation to assassinate in particular circumstances that transcends pertinent treaty prohibitions. To argue the first would

65. See generally Draft Articles on the Draft Code of Crimes Against the Peace and Security of Mankind, Dec. 4, 1954. U.N. Doc. A/46/405 (1991), 30 I.L.M. 1554 (1991); reprinted in 2 Weston II.E.5.(as revised by the International Law Commission, through 1991).

66. See Hague Convention IV, Respecting the Laws and Customs of War on Land, with Annex of Regulations, done Oct. 18, 1907, entered into force for the United States, Jan. 26, 1910, 36 Stat. 2277, 1 Bevans 631. 
focus primarily on a "linguistic" solution. To argue the second would be to return to the historic natural law origins of international law. ${ }^{67}$

Natural law remains, beyond any doubt, the foundation of all international law. ${ }^{68}$ This understanding was reaffirmed explicitly at Nuremberg. ${ }^{69}$ Although the indictments of the Nuremberg Tribunal were cast in terms of positive law, the actual judgments of the Tribunal unambiguously reject the proposition that the validity of international law depends upon its "positiveness," that is - upon its precise and detailed codification. The words used at Nuremberg - "So far from it being unjust to punish him, it would be unjust if his wrongs were allowed to go unpunished" $"$ stem from the peremptory principle: Nullum crimen sine poena, "No crime without a punishment."11 This principle stands in sharp contrast with the central idea of jurisprudential "positivism," that is, the exclusive idea of law as the command of a sovereign.

The aforementioned arguments concerning assassination as anticipatory self-defense are strengthened by the underlying and important expectations of

67. For a comprehensive assessment of the natural law origins of international law by this writer, see Louis Rene Beres, Justice and Realpolitik: International Law and the Prevention of Genocide, 33 AM. J. JURIS. 123 (1988). This article was adapted from a presentation by this writer at the International Conference on the Holocaust and Genocide, Tel-Aviv, Israel, June 1982.

68. Vattel identifies the immutability of certain peremptory norms (jus cogens) with their basis in Natural Law:

Since, therefore, the necessary Law of Nations consists in applying the natural law to States, and since the natural law is not subject to change, being founded on the nature of things and particularly upon the nature of man, it follows that the necessary Law of Nations is not subject to change. Since this law is not subject to change, and the obligations which it imposes are necessary and indispensable, Nations can not alter it by agreement, nor individually or mutually release themselves from it.

VATTEL, supra note 4 , at 4 .

69. See Intermational Conference on Military Trials 223, London 1945. Report of Robert H. Jackson, Department of State, I.O.C.S. II, European, 1. The Judgment of the IMT of October 1, 1946 rested upon the four Allied Powers' London Agreement of August 8, 1945, to which was annexed a Charter establishing the Tribunal. Nineteen other states subsequently acceded to the Agreement. In addition to the forty-two volumes of official documents on the Nuremberg Trial of the Major War Criminals Before the International Military Tribunal published by that Tribunal (1947-49), the United Nations War Crimes Commission selected and edited eightynine additional cases, published in fifteen volumes as Law Reports of Trials of War Criminals (1947-49).

70. See A. D'Entreves, Naturallaw: An InTroduction To legal Philosophy 106 (1970). Nullum crimen sine poena is the principle that distinguishes between criminal and civil law. Without punishment there can be no distinction between a penal statute and any other statute. See Redding v. State, 85 N.W. 2d 647, 652 (Neb. 1957) (concluding that a criminal statute without a penalty clause is of no force and effect). The earliest statements of Nullum crimen sine poena can be found in the ancient Code of Hammurabi (c. 1728-1686 B.C.); the Laws of Eshnunna (c. 2000 B.C.); the even-earlier Code of Ur-Nammu (c. 2100 B.C.); and the Lex Talionis or law of exact retaliation presented in three separate passages of the Jewish Torah or Biblical Pentateuch.

71. BLACK'S, supra note 63 , at $1068,1155,1385$. 
natural law-expectations that are always peremptory, are always above the particular constraints of human lawmaking and always of special relevance to Americans. For Blackstone, writing in the Fourth Book of his Commentaries, "Of Public Wrongs," it was essential to transform "the eternal, immutable laws of good and evil" into a practical and operational code. ${ }^{72}$ As a starting point for understanding the common law, the Commentaries reveal that all international law, or what Blackstone calls the Law of Nations, is "deducible" from natural law and therefore binding upon each and every state. ${ }^{73}$ Thus, each state is called upon "to aid and enforce the law of nations, as part of the common law, by inflicting an adequate punishment upon offenses against that universal law. ..."74

When Thomas Jefferson set to work on the Declaration of Independence, he drew freely upon Aristotle, Cicero, Grotius, Vattel, Pufendorf, Burlamaqui and - especially - John Locke. Asserting the right of revolution whenever government becomes destructive of "certain unalienable rights," the Declaration posits a natural order in a world whose laws are external to human will and which are discoverable through human reason. Although, by the eighteenth century, scholars had come to view God as having withdrawn from immediate contact with humankind (thereby transforming God into the "Prime Mover" of the universe), "nature" provided an apt substitute. Reflecting the decisive influence of Isaac Newton, whose PRINCIPIA was first published in 1686, all of creation was now taken as an expression of Divine Will. Hence, the only way to know God's will was to discover natural law. Locke and Jefferson had deified nature and denatured God.

The theory of natural law, which is found, inter alia, in the Declaration and in the Bill of Rights, is based on clarity, self-evidence and coherence. Its validity cannot be challenged by considerations of power politics. To ignore any assassination imperatives that might lie latent in these documentary foundations of the United States - in particular, as we may be facing terrorist harms inflicted by weapons of mass destruction - would be illogical and selfcontradictory, as it would nullify the immutable and universal law of nature from which these documents derive.

We observe, therefore, that U.S. responsibility to ensure punishment ${ }^{75}$ and defend against terrorism derives not only from the explicit expectations of international law, but also from the natural law foundations of American

72. See William Blackstone, Blackstone's Commentaries on the Laws of ENGLAND, bk. 4 ch. I. (Wayne Morrison ed., 2001).

73. See id.

74. Id. at 73.

75. Imposing punishment for crimes is an essential part of all international criminal law. Ongoing venues for such punishment are the International Criminal Tribunals for the former Yugoslavia (ICTY) and Rwanda (ICTR). See generally Andrew N. Keller, Punishment for Violations of International Criminal Law: An Analysis of Sentencing at the ICTY and ICTR, 12 IND. INT'L \& COMP. L. REV. 53 (2001). 
municipal law. ${ }^{76}$ In the strictest sense, the natural law foundations of our municipal law are not a distinct alternative to international legal norms, but rather a distinct source of international law. According to Article 38 (c) of the Statute of the International Court of Justice, international law stems in part from "the general principles of law recognized by civilized nations." means nothing less than that the U.S. Declaration of Independence and Bill of Rights represent an authoritative source of international legal norms. Indeed, contemporary international law displays an even more explicit debt to these documents by identifying an "International Bill of Rights"78 at the very cornerstone of a binding, worldwide human rights regime - a regime that includes, inter alia, freedom from terrorism-inflicted harms. It follows from all this that any U.S. initiative to punish and prevent aggression, terrorism and related crimes against humanity by assassination of Saddam Hussein could represent essential support for international law directly and for our own founding principles.

76. According to Clinton Rossiter:

Yet, the most compelling explanation is the American's deep-seated conviction that the Constitution is an expression of the Higher Law, that it is in fact imperfect man's most perfect rendering of what Blackstone saluted as 'the eternal, immutable laws of good and evil, to which the creator himself in all his dispensations conforms; and which he has enabled human reason to discover, so far as they are necessary for the conduct of human actions.'

EDWARDS. CORWIN, THE "HIGHER LAW" BaCKGROUND OF AMERICAN CONSTITUTIONAL LaW, vi Prefatory Note (1928).

77. See U.N. CHARTER, done San Francisco, June 26, 1945, entered into force for the United States, Oct. 24, 1945, 59 Stat. 1031, T.S. No. 993, 3 Bevans 1153, 1976 Y.B.U.N. 1052 .

78. The International Bill of Rights consists of the human rights provisions of the UN Charter; the Universal Declaration of Human Rights; the two International Covenants on Human Rights and the Optional Protocol to the Covenant on Civil and Political Rights. See generally Louis Henkin, The International Bill of Rights: The Universal Declaration and the Covenants, in INTERNATIONAL ENFORCEMENT OF HUMAN RIGHTS 1 (R. Bernhardt \& J.A. Jolowicz eds., 1987). 
